\title{
An exploration of the effect of servicescape on student institution choice in UK universities
}

\section{Abstract}

In recent years there has been increased discussion of the subjective, emotional and sociological factors influencing student choice of university. However there is a dearth of information exploring what constitutes these feelings. This exploratory paper uses the conceptual model of the servicescape to provide insight into the emotional factors driving student choice.

\section{Introduction}

With the 2012 introduction of increased fees and the stagnation of graduate 
1 environment; universities vie to attract prospective students and choice of university

2 has become a more complex decision making process. This has led to the

3 marketisation of HE (Gibbs, 2001) and as a natural consequence, the desire to better

4 understand student choice of university.

As with any consumption behaviour, university choice is driven by both rational and emotional factors (Angulo, Pergelova, \& Rialp, 2010). Rational influences include career prospects (Maringe, 2006) and distance from home (Briggs, 2006). Emotional factors are those which are more subjective or sociologically grounded; they are driven by whether or not the institution has a good 'atmosphere' (Pampaloni, 2010).

Whilst there has been increased discussion of their presence, there is a dearth of information to explore what constitutes these subjective feelings. Obermeit (2012) suggests the quantitative nature of many studies means there is insufficient qualitative information to explain variables; asking large samples of students whether atmosphere is important does not explain why it is important or indeed, what it is. This should concern university marketing decision makers; if reasons driving student choice are not fully understood, universities cannot expect to market and differentiate themselves successfully.

The provision of education is a service. Within their extensive examination of services marketing literature, Zeithaml, Parasuraman \& Berry (1985) identify four key characteristics of services: intangibility, inseparability of production and consumption, heterogeneity and perishability. These four characteristics are all present within education: education is inherently intangible; product and consumption - teaching and learning - are 
simulataneous; the provision of education varies greatly between institutions; and education cannot be stored. Indeed, in recent years HE has been widely acknowledged as being within the service industry and therefore managed as a service sector business (Hemsley-Brown \& Oplatka, 2006). That said, HE is a complex service and there are "differences in context between HE institutions and other service organisations" (Hemsley-Brown \& Oplatka, 2006, p. 8): the variety of HE offerings and the increasing number of institutions makes comparisons difficult; consumer decision making is highly involved and complex; and purchase is very infrequent. However as Mazzarol (1998, p. 164) says: "education remains a service capable of treatment as any other in terms of marketing theory" Taking this argument further, when considering education as a service, students can be considered as co-producers of that service - student participation and involvement within their own learning experience is a critical success factor. For this reason, academics posit HE is an experiencecentric service (Jarvis, 2000; Petruzzellis, D'Uggento, \& Romanazzi, 2006). Here, the customer experience - 'experience' being some level of interaction between the customer and the service provision - is at the heart of the service offering and is deliberately created to provide a service distinguishable from competitor's offerings (Voss, Roth, \& Chase, 2008). The premise of experiential marketing is that it facilitates subjective or emotional decision making. Functional values are replaced by customer experiences (Schmitt, 1999) and the environment in which these values are delivered is central to the customer's perception of the experience (Zomerdijk \& Voss, 2010). With this in mind it is unsurprising that within 
the HE environment, the Open Day - which deliberately offers the opportunity to sample the service environment and experience - is cited as a key factor in student decision making (Briggs, 2006; Connor, Burton, Pearson, Pollard, \& Regan, 1999; Pampaloni, 2010; Veloutsou, Paton, \& Lewis, 2005)

Whilst it is agreed that the open day is a key factor in decision making, little is known about how it influences prospective students. It is therefore suggested that alongside other marketing tools and techniques that have been applied to HE as a service organisation, a closer look at the service environment itself - the servicescape - is now required.

This study uses the conceptual model of servicescape to provide an insight into the emotional factors driving student choice of university. This will result in a greater understanding of how the service environment impacts prospective students and furthermore, it will facilitate further comprehension of the subjective decisions underpinning choice of university.

\section{$6 \quad$ Literature Review}

\section{The concept of Servicescape}

8 The impact of the service environment on consumers has long been acknowledged;

9 drawing on environmental psychology studies, Kotler (1973) explored the concept

20 of 'atmospherics' within a retail setting. However it was Booms and Bitner (1981)

21 who first put forward the term 'servicescape' to refer to the physical environment in

2 which a service is delivered. Bitner (1992) drew on the extant literature at the time

3 to present a conceptual model which outlined the servicescape as being defined by

24 three distinct physical areas - i) ambient conditions - elements which are normally 
subconscious, such as temperature, lighting, background noise, music and scent; ii) spatial layout and functionality - the size, style and arrangement of the furniture and equipment and the degree to which it facilitates both production and consumption; and iii) signs, symbols and artefacts - the explicit and implicit signs communicating instructions, directions or image. More than twenty years later, these distinctions are still perceived to be relevant and an accurate reflection of a physical service environment (Mari \& Poggesi, 2013).

Although most frequently been applied to retail settings, the concept of physical

9 servicescape is equally applicable in a non-retail setting (Rosenbaum \& Massiah, 2011);

10 indeed Bitner (1992, p. 57) acknowledges previous studies that consider the impact the

11 physical environment has on behaviour within 'hotels, restaurants, professional offices,

12 banks, retail stores and hospitals'. It is therefore felt the educational environment is

13 equally applicable, especially given the growing interest in student centred learning is

14 leading a number of $\mathrm{HE}$ institutions to consider a more deliberate design of their

15 environments to promote better teaching, learning and interaction (Radcliffe, Wilson,

16 Powell, \& Tibbetts, 2008).

17 Bitner's servicesape model has been reviewed and developed only by a handful

18 of authors (Mari \& Poggesi, 2013) who, almost without exception, point to considering

19 the impact of social or human factors alongside the physical service environment

20 (Aubert-Gamet, 1997; Aubert-Gamet \& Cova, 1999; Bonnin, 2006; Esbjerg \& Bech-

21 Larsen, 2009; Harris \& Ezeh, 2008; Rosenbaum \& Massiah, An expanded servicescape

22 perspective, 2011; Tombs \& McColl-Kennedy, 2003). The social dimension of

23 servicescape therefore encompasses the presence of, and interaction between, 'staff' and

24 'customers'. 
2 (2011) posit the existence of two additional socially directed dimensions: the socially

3 symbolic dimension and the natural or restorative dimension.

5 purposefully employed to appeal to 'groups of customers with a unique ethnic, sub-

6 cultural, or marginalized societal status' (Rosenbaum \& Massiah, An expanded

7 servicescape perspective, 2011, p. 478). As the vast majority of HE environments are

8 committed to equality and diversity, overt social symbolism is unlikely to be applicable

9 to the university servicescape. However a broader view of social symbolism could be

10 the way in which a service environment is generally crafted to appeal to certain groups

11 of people.

The natural or restorative dimension has three stimuli: i) being away- a sense of escape from 'day after day concerns'; ii) fascination - the ability to effortlessly hold somebody's attention; and iii) compatibility - the ability to create a feeling of

15 belonging.

\section{Implications of the Servicescape concept}

17 The concept of servicescape is underpinned by Mehrabian and Russell's (1974)

18 Stimulus-Organism-Response (S-O-R) model which explains the mechanism of how

19 individuals respond to environmental stimuli. Bitner (1992) suggested consumers will

20 have a cognitive, emotional and/or physiological response to the service environment

21 and that the degree of cognitive/emotional/physiological response will determine the

22 individual's ultimate behaviour - either approach or avoidance. Whilst there is criticism of the simplicity and linear representation of the S-O-R

24 model itself (Donovan \& Rossiter, 1982; Jacoby, 2002; Mari \& Poggesi, 2013) it does 
1 reflect at some level that consumer behaviour is influenced by the holistic environment

2 of the consumption setting. If it is agreed that HE is an experience-centric service, then

3 it should follow that the environment where that service is provided - the institution

4 itself - should be deliberately crafted to encourage emotional decision making.

5 Developing this argument further, the concept of servicescape integrating S-O-R where

6 emotional responses are known to determine behaviour, becomes highly relevant to the

7 learning environment; in fact, Mehrabian \& Russell (1974) themselves suggest the

8 application of S-O-R to education. Despite this, there does not appear to be any

9 research that explores the conceptual application of servicescape in an educational

10 context.

11 Consumer decision making, and university choice is no exception, is driven by

12 both rational and emotional factors (Angulo, Pergelova, \& Rialp, 2010). Rational

13 influences are those which are considered to be more objective and where information

14 can be sought to support the decision making; within the realm of university choice this

15 includes career prospects (Maringe, 2006) and the distance away from home (Briggs,

16 2006). Emotional factors are those which are more subjective or personally felt and

17 supporting information is not available; they include, for example, the student's 'own

18 perception' (Briggs, 2006) as to whether the institution 'feels right' (Allen, 2002).

19 In reviewing the extant literature on student choice there are two clear areas that

20 are underpinned by the concept of servicescape - the influence of the physical

21 environment and the emotional drivers behind student decision making. In terms of

22 how the physical environment influences student decision making, the consensus is

23 'place', 'facilities' and 'campus' are determinants of student choice of institution

24 (Angulo et al, 2010; Ivy, 2008; Maringe, 2006; Mehboob, Shah, \& Bhutto, 2012; 
1 Veloutsou et al, 2004). However there is little in the way of exploration with regards to

2 why, how or which elements of campus, facilities or place is important.

4 decision making: Allen (2002) presents a framework explaining how rational choice for

5 postsecondary education is driven by the sense that the institution 'feels right';

6 Diamond, Vorley, Roberts, and Jones (2012) suggest the 'feel' of a university is key;

7 Moogan, Baron \& Bainbridge (2001) found that 'atmosphere' experienced at open day

8 influenced UK student decision making, as did Pampaloni (2010), who highlights

9 'atmosphere' as the ultimate reason for application for almost $60 \%$ of US students.

10 Similarly Briggs (2006) cites 'own perception' amongst the top ten factors for Scottish

11 university choice. Whilst they all acknowledge that the feel of a university is a key

12 determinant for prospective students, nobody elaborates on what is actually meant by

13 atmosphere. The Oxford English Dictionary defines atmosphere as the "pervading tone

14 or mood' which suggests that 'atmosphere' is emotional rather than physical, but it does

15 little to illuminate what the atmosphere at a university might be. It is known, however,

16 that within the concept of servicescape, the intention is to use the physical setting to

17 create an atmosphere which will influence behaviour (Bitner, 1992)

18 And so the argument returns full circle and together, these two literature gaps

19 provide credence to exploring drivers of student choice using the servicescape model.

20 To address these gaps, this study explores the effects of the holistic university

21 servicescape and uses it to provide an insight into the emotional factors driving student

22 choice. Specifically the study seeks to explore:

23 1) The relative importance of the servicescape dimensions

24 2) The emotional and cognitive responses triggered by the dimensions of servicescape 


\section{$7 \quad$ Methodology}

8 Methodologies for previous studies on student choice have been largely quantitative in

9 nature (Obermeit, 2012, p. 217), providing respondents with 'a limited number of

10 response options' and therefore there is a need for exploratory, qualitative work to

11 explore the factors behind student choice. Although the nature of this research project

12 considers external objects - the constructed physical and social environment - it is the

13 way in which these are interpreted or perceived that is of relevance. Therefore this

14 study follows a phenomenological philosophy and takes an inductive approach to understand the significance of the university servicescape and its impact on resultant behaviours.

\section{Data collection}

18 Qualitative data was gathered through semi structured interviews which aimed to create 19 a picture of the respondents' true feelings (Chisnall, 1992), thereby providing a deeper

20 understanding of the impression left by the university servicescape. Semi structured

21 interviews were chosen as the standardisation of some questions increases the reliability

22 of data collection, and yet the format still provides a degree of spontaneity by allowing

23 the interviewer to probe and explore responses (Cohen \& Crabtree, 2006). 
As it was equally important to speak with students for whom the servicescape

2 triggered avoidance behaviours and as those for whom it triggered approach behaviours,

3 prospective students attending university open days (rather than existing students) were

4 the population for this research. Telephone interviews were undertaken with a sample

5 of 24 participants considering business related courses. Participant details are outlined

6 in Table 1. Participants were recruited from the open day guest lists from two UK south

7 coast universities although in order to ensure validity of the data gathered, the

8 interviews explored participants' reflections and experiences at all open days they had

9 attended, not just the open day where they were recruited. The sample size was

10 considered appropriate for an exploratory study and exceeds those previously used

11 within qualitative studies researching student choice (Obermeit, 2012), such as Baker

12 and Brown (2007) - 13 participants; Brown et al (2009) - 22 students; and Moogan et al

13 (1999) - 19 students. Data saturation, the point at which no new information is

14 uncovered (Mason, 2010), was reached after 18 interviews and therefore the sample size

15 is robust and offers indicative results that are representative (Miles \& Huberman, 1994).

16 [Table 1 near here]

17 To ensure the experience and resulting perceptions were fresh in their minds',

18 telephone interviews were conducted with participants within a week of their attendance

19 at the Open Day. The duration of the telephone interviews was, on average, 37 minutes.

20 The particular topics explored during the interview were as follows:

21 - How it was decided which open days to attend and what were the expectations

22 of the university servicescape based on material viewed prior to visit

23 - What were the impressions of the servicescape experienced at open day and

24 what were the thoughts and feelings it created 


\section{Findings and discussion}

14 Consistent with much of the extant literature on student choice (Allen, 2002; Briggs,

15 2006; Pampaloni, 2010), a number of respondents made comment that a specific university 'just feels right'. However the use of probing in interviews and the mapping

17 of comments to the conceptual framework of the servicescape during analysis,

18 uncovered key factors contributing to this state.

\section{The servicescape as a driver for shortlisting universities}

20 Amongst all participants there was acknowledgement that university selection is a

21 multilayered process that begins with compiling a shortlist of universities to visit, and

22 ends with reflection on the different institutions and a comparison of the overall 
Students have an idea of what they think university is like based on little more

2 than expectations and anecdotal evidence from friends or family. Expectations seemed

3 to be related to the size of the institution - 'it's just sixth form college but a bit bigger' -

4 and anecdotal evidence was generally directed at the location rather than the university

5 itself - 'my mum said it was the second roughest city in the UK'. Whether their

6 preconceptions are valid or not is, at this juncture, slightly irrelevant. If there were

7 sufficient negative preconceptions, the university didn't make it on to the shortlist.

Alongside individual perspectives on geographical location and personal

9 recommendation from either friends or family, the university website and prospectus

10 form a key part of the evaluation process by shaping initial impressions of an institution.

11 This links to findings by Connor et al (1999) Diamond et al (2012) and Moogan et al

12 (2001) who all cite the prospectus as a key tool facilitating decision making. More

13 specifically, over half the participants stated the photographic and written portrayal of

14 the physical servicescape within the university website or prospectus played a part in

15 their shortlisting.

16 Whilst they make good use of website and prospectus material, students readily

17 accept that the images portrayed are ones which illustrate the best facets of the

18 university. Some participants were more cynical in their appraisal of images, stating

19 that photographs do not necessarily convey the reality:

20 Pictures on a website or in a prospectus can be a bit misleading... you can't get a

21 sense of scale from website pictures.

23 You don't put a picture on that shows your flaws... the pictures make you look as

24 attractive as you can. 
One participant talked eloquently of 'websites giving false impressions', and he

2 therefore 'stopped looking at websites other than for course content', and was focused

3 on 'getting the feel of the place on open days.'

That said, both the website and prospectus can be powerful image creating tools

5 for universities and through description and photographic images, they portray an image

6 of the physical, social and natural dimensions of servicescape. All participants

7 reviewed either one or both of these in preparation for an open day visit and in the vast

8 majority of cases, looking through university produced material was the only

9 preparation the respondents undertook prior to an open day. Some participants talked

10 about informally discussing open day visits with friends, thus linking with the general

11 agreement that friends and family can be a key influence in decision making amongst

12 students of any nationality (Briggs \& Wilson, 2007; Cabrera \& La Nasa, 2000; Dawes

$13 \&$ Brown, 2008) and a small number of participants also looked at independent sources

14 such as league tables.

\section{The need to 'experience' the servicescape}

16 Whilst university produced marketing material is used as a preliminary filter, it is

17 accepted that it is not a substitute for personal experience of an institution. An open

18 day, or visit, allows the first impressions gleaned from the web and prospectus to either

19 be reinforced or damaged:

What you see on paper doesn't necessarily convey the atmosphere.

Once there, it becomes more real.

Participants talked of emotional responses to the overall university servicescape;

24 personal responses that arise only as a reaction to physically being within the 
1 environment which cannot be easily conveyed through the prospectus or website. For

2 example 'the campus felt comfortable' or that 'it was cosy and felt safe'. This draws

3 directly on Mehrabian and Russell's (1972) S-O-R theory which reflects upon the

4 emotion-eliciting qualities of environments.

This, in marketing terms, clearly reinforces the experiential nature of HE and

6 emphasises the possibilities for institutions to adopt experiential branding.

7 Consequently all respondents supported previous research on student choice (Briggs,

8 2006; Connor et al, 1999; Pampaloni, 2010; Veloutsou et al, 2005) in agreeing the open

9 day is a key factor in decision making, with comments such as: 'It will probably always

10 be different in your mind to what it actually is' and 'You will never get a better

11 impression than when you actually see it properly.'

\section{First impressions do count, but some more than others}

\section{The physical dimension of servicescape is a hygiene factor}

14 Students have a set of expectations for how a university should look. Specifically they

15 expect buildings to be aesthetically pleasing, clean and obviously well maintained - a

16 view expressed by 22 out of the 24 participants. Whilst these are clear expectations,

17 they do not appear to trigger approach behaviours in themselves; rather they are hygiene

18 factors and the absence of them creates avoidance behaviours.

19 If it looked old then I would think “oh no, I don't want to go here”.... that would be 20 behind the times.

The feel and look of the buildings needs to be new but not necessarily modern. that needed a refurb, I wouldn't like that. It needs to look well cared for. 
2 tuition fees. As one participant said: shabby.

Bitner (1992) suggests that the physical servicescape elements trigger either a

6 cognitive or emotional response which leads to approach or avoidance behaviour.

7 Participants' comments suggest that the physical dimension of the university

8 servicescape leads to a cognitive response - their aesthetic and state of repair is a non-

9 verbal communication reflecting the care and consideration taken by the university.

10 The underlying implication is that a lack of care and attention for university buildings

11 would be a reflection of a lack of care and attention in respect of the education

12 provision:

Exterior environments seemed to resonate on a conscious and subconscious

level. Whilst participants were not expressing the need for cutting edge design and décor, several negative comments were made about buildings that were 'grey and ugly',

20 with participants even altering perceptions and rankings for universities where the

21 campus seemed 'too concrete'. Perhaps therefore, there is a subconscious desire for an emotional reaction to university building; to be slightly excited by them? As one participant put it: want to go there; it's not very appealing. 
2 citing a 'modern exterior' as being aesthetically pleasing, there was much less to be said

3 about the interiors. Only five participants passed comment on the interior of buildings

4 and the comments referred to what Bitner (1992) called the 'ambient conditions' - the

5 light, colour, standard of cleanliness and a sense of space.

6

7 The social dimension of servicescape, specifically interaction with staff, leads to

8 approach/avoidance behaviours

9 The formation of the social servicescape arises from the inclusion of people within the

10 physical servicescape. Unsurprisingly all participants cited both the staff and students

11 involved in the open day as being key components in forming impressions of that

12 university. However unlike the physical dimension of servicescape which elicited a

13 cognitive response, the social dimension elicited an emotional response - pleasure or

14 arousal. Whilst the concept of social servicescape includes the impact of over and

15 undercrowding, the number of other people present at an open day did not cause

16 significant comment from participants; discussion centred around the social encounters.

17 Of all the social encounters at open day, participants felt the course talk was the 18 greatest opportunity for an impression to be made and this was most likely to affect the

19 participant's state of arousal. Unsurprisingly then, the course talk was discussed much

20 more frequently than any other aspect of the social servicescape. Twenty-three out of

2124 participants specifically discussed the course talk when describing their open day experiences and 18 said this created the key impact for the open day, adding credence to

23 previous academic research where the quality of teaching or reputation of teaching staff

24 has been cited as a key determinant of choice (Moogan \& Baron, 2010; Palacio, 
1 Meneses \& Perez Perez, 2002; Price et al, 2003). Participants appeared unconcerned

2 with the academic standing of the staff - research was not mentioned at all within the

3 interviews - but it was clear there was a need for staff to inspire. A view supported by

4 Maringe (2006) who found that teaching reputation was more important for students

5 than research profiles. Being able to interact with staff was felt to be important and this

6 is generally offered through the course talk. Engagement emerged as being critical. It

7 is not sufficient for staff to be knowledgeable and polite - staff that were 'enthusiastic',

8 'passionate' or 'engaging' triggered approach behaviours and staff that weren't,

9 triggered avoidance behaviours: giving me the best impression... if this is what it is like on Open Day what on earth would it be like on a normal day? experience. If the staff are not engaging, that does matter. in your head... it [the course talk] was a little bit funny, a little bit light hearted. It kept 21 the mood up'.

Conversely a dry, un-engaging course talk, or one that focuses too much on one aspect, was remembered as a negative experience and triggered avoidance behaviour.

24 Some participants explained how choices and institution preferences were re-evaluated in favour of those with a more engaging course talk 'that brought the course to life a bit more' and more crucially, none of the participants were prepared to include a university with a 'poor' course talk on their final preference list. This links with the findings of 
1 Moogan et al (1999) who say that open day experiences are crucial in final evaluation

2 stages and can be influential in changing prospective students' minds. loved it.

Student talks and student ambassadors or representatives were also considered

6 important in 'getting the real story' and adding to the 'buzz and the campus feel';

7 'friendliness' and a 'welcoming attitude' were valued. This is explored further below.

8 The natural dimension of servicescape is a key trigger of approach/avoidance

9 behaviours

10 Students need somewhere 'to escape'. Rosenbaum and Massiah (2012) highlight three

11 key stimuli that provide the natural, restorative servicescape which are 'being away,

12 fascination and compatibility'. Of these, the provision of a 'being away' stimulus - the

13 ability to offer a sense of escape from 'day after day concerns' (Rosenbaum and

14 Massiah, 2012, p480) was seen as a huge draw and triggered a positive emotional

15 response. Prospective students highlighted natural environments as being ideal for

16 creating the feeling of 'being away' - grassy areas, trees, parks, playing fields, seaside

17 locations - and the ability to escape was cited by a number of participants as being

18 important:

19 It's nice to know I can sit on the grass and chill out a little bit.

It's not too far from the seaside - if you ever had a bad day you could just go and take a walk.

Going down to the seaside is a nice little break. It's relaxing; the air was fresher; it's not such a rush as it is up here [home city]. 
Similarly, the lack of any green space was seen as a negative factor:

It felt like you were never going to really get away from the university because of its dominant presence within the town.

I need to feel as though I am not cooped up.

The desire for a natural restorative servicescape is interesting as often, and especially for non-campus universities, this natural environment is provided by the location itself rather than the university.

Linking in with the desire to have some physical relief from a study environment, sports facilities were singled out among some participants as being noteworthy, with the presence of good sports facilities engendering a positive impression of the servicescape and subsequent approach behaviour. It was also interesting that few students made specific mention of some of the more recent additions to campuses such as branded coffee shops, cafes etc. Whether this is because they are now just accepted as part of the general environment, or are not considered important, is interesting.

A feeling of belonging is crucial. Whilst 'fascination' - the ability for the university servicescape to hold a student's attention - was not considered by participants to be important, the notion of 'compatibility' - the ability of a university to provide a 'sense of belonging' (Rosenbaum and Massiah, 2012, p480) was seen as being essential and when specifically asked for the key reasons for choosing one university above another, the feeling of belonging was cited in some form by all participants, thus highlighting that a positive emotional, rather than a cognitive, response to the servicescape is a key indicator of approach behaviour. In most cases (20 out of 24 participants) this was 
1 created from the social dimensions of servicescape, in particular a positive atmosphere

2 created by 'friendly' students, staff or locals. Students being helpful isn't enough; as

3 one participant said:

4

5

6 8 just those involved in the open day - was cited by some participants:

I assume everyone at the Open Day is going to be helpful; the students seemed as though they wanted to be there; they seemed genuine and made it seem friendly and casual.

We go and find some students. Not the ones who are wearing the badges because they are supposed to say nice things... then you get a proper insight not just the selling vibe. Honesty is important.

More specifically for many participants, the sense of belonging was recognised to this as 'student-institution fit': don't like it [the university] and they aren't like you, then that is a good thing. It is a conscious decision to see if I fit in. You need to see how students [at that university] are behaving... whether you see yourself as that kind of person and you want to be around people like that. like people who are similar to me.

A desire to ensure that all students contributed to a positive environment - not after a conscious decision to evaluate the other students with participants revealing that they actively considered whether they 'could get along with' other open day guests and existing students. Citing Banning and Banning (1986), Price et al (2003, p. 213) refer 
2 students after the open day, by looking at the profiles of individuals who were tweeting

3 about a specific university.

The theme of self-reference emerged very strongly with all except two participants saying they needed to 'be comfortable', 'fit in' or 'see myself there'. This

6 was not only engendered by the social dimension of servicescape; the physical

7 environment of both the university and also the wider physical environment of the city

8 or town, was seen as having a role to play in creating the sense of compatibility:

If it looks clean and safe you will keep wanting to go back. buildings] environment has to be one where I feel comfortable ... and that I am going to do a lot of work in.

for those participants seeking the perceived safety and security of a campus based

19 university.

The sense that belonging can also arise from the physical servicescape blurs the

21 boundaries between the dimensions of social symbolism and the compatibility element

22 of the natural servicescape. Taken in the broadest sense, social symbolism can be interpreted as the deliberate crafting of the environment to appeal to certain groups of

24 people; in this situation, prospective students are the desired audience. If the environment is such that it appeals strongly, then it follows that a sense of belonging will be created. 


\section{Conclusions}

2 The core contribution of this research lies in examining the role of the service

3 environment in the emotional factors driving student choice of university. In taking

4 Rosenbaum \& Massiah's (2011) servicescape model and applying it to Higher

5 Education within the UK, the research provides insights into the impact of the

6 university service environment on prospective students and its resulting effect on

7 decision making. A number of elements were particularly significant:

8 Assuming there are no significant negative preconceptions of the university,

9 websites and prospectuses are important in creating a significantly positive impression

10 of the university servicescape to encourage attendance at an open day. However once

11 the prospective student attends the open day, the written and visual impression provided

12 by the website and prospectus loses its significance; there is a need to 'fit in' with the

13 actual university environment experienced at the open day. The need for a sense of

14 belonging during the open day emerges as extremely important in the decision making

15 process. This element of self-reference is interesting as it resonates clearly with the

16 social and socially symbolic dimensions of the servicescape model adopted. However

17 this does present a challenge in practical terms; can social symbolism and compatibility

18 be deliberately created, managed and maintained especially when some of it stems from

19 the wider environment of the location. Clearly further work is needed to consider this.

20 Other factors in the open day experience are evidently more pragmatically

21 viewed. Buildings, for example, are hygiene factors that do not trigger positive

22 approach behaviour on their own, but can trigger avoidance behaviour where they are

23 seen negatively. This has very clear implications for management of the university

24 experience in general, with the first impressions at open day being particularly poignant. 
Websites and prospectuses may attempt to create impressions of the natural,

2 'being away' elements of servicescape but this servicescape dimension needs to be felt

3 at the open day itself. An understanding of how a university might provide this element

4 is evidently very important for those who seek to optimise the open day experience, as

5 our work indicates that the presence or absence of the natural dimension (e.g. parks,

6 green spaces, beaches) will strongly trigger approach/avoidance behaviours. In many

7 locations the town or city already has a natural, restorative servicescape; close work

8 with civic counterparts may help to showcase this.

The importance of interactions with people, in particular academics, should not

10 be underestimated; the social dimensions can elicit a significant emotional response

11 resulting in ultimate approach behaviour and were overwhelmingly discussed as

12 important by our sample, and key in facilitating a feeling of belonging.

13 Broadly speaking the findings resonate with Rosenbaum and Massiah's (2011)

14 servicescape model, demonstrating its relevance to the HE environment and

15 contributing significant value to both academics and practitioners. That said, the

16 findings suggest some overlap between the dimension of social symbolism and the

17 element of compatibility within the natural dimension; further work to provide clearer

18 distinction or the nature of the relationship between the two would be welcome.

19 The findings from this study also draw on an interesting debate within the field

20 of place branding of how 'place' can be defined. Whilst Bitner's work considers the

21 discrete and deliberately crafted service environment created by the provider, place

22 branding literature argues that place is more fluid and is a relative concept (Hanna \&

23 Rowley, 2011; Warnaby, 2009). Participants' perceptions of what was included within

24 the university servicescape often extended beyond university buildings, staff and

25 students, to include elements of the wider location: for example, the natural restorative 
1 servicescape that was provided by the civic park or local coastline; the friendliness of

2 the local residents; the sense of 'fitting in' not just at the university but also within the

3 city or town. This should be of great interest to university marketing decision makers

4 and it is suggested that further work is undertaken to explore the perceived contribution

5 of location to the university.

6 Whilst this study specifically offers clarification of the key servicescape

7 dimensions within the UK HE market, HE provisions outside the UK are also

8 increasingly subject to market pressures and therefore this research offers genuine

9 insight for both theory and practice in the UK and beyond. Clearly however, it is an

10 initial step and further research is outlined below. Ultimately a specific model that

11 allows conceptualisation and management of the HE servicescape dimensions would be

12 desirable.

\section{Implications for managers}

14 A number of practical implications are apparent:

15 Maintenance of the physical elements of the servicescape, such as upkeep and

16 cleaning of buildings, are important as students talked of 'judging a book by its cover'.

17 Interestingly maintenance might be considered to be more critical than investment or

18 development of buildings and interiors, which is expected to some degree. A lack of

19 maintenance, and therefore a perceived lack of care, creates a significant negative

20 response, triggering avoidance behaviour. Investment or development of buildings does,

21 of course, result in significant and longer term infrastructure projects for universities;

22 changes will inevitably have significant time and cost implications. However the

23 portrayal of physical servicescape within the website and prospectus are still important 
1 in the initial filtering process and therefore should be actively managed by the

2 institution to create a positive impression.

The social aspect of the open day experience (eg happy staff and students) is

4 clearly very important as part of the servicescape. Whilst this is perhaps unsurprising, it

5 is evident that some institutions still have issues managing this important element. It is

6 of course inherently difficult to manage and control but its importance makes

7 addressing this a priority.

An understanding of the natural restorative elements of servicescape is helpful to

9 HE managers; there is a need to highlight a sense of escape, both in communications

10 material and during the open day itself. For campus based institutions this may involve

11 deliberate creation, and highlighting of, green outside space. However for all

12 institutions, but particularly non campus based, the practical focus is on working with

13 civic counterparts in maximising this.

14 An acknowledgement is required that from the prospective student's point of

15 view, the boundary between the university and location is blurred. Whilst the university

16 owns and can therefore control its own physical servicescape, there are elements of the

17 wider environment that are outside of its control and yet are key factors in student

18 decision making. The provision of a natural, restorative servicescape is a good example

19 of this.

Finally, but arguably most significantly, creating that elusive sense of belonging

21 appears to be critical. Whilst this is of course difficult, university managers need to both

22 acknowledge and better understand how to create that 'I could see myself here' feel at

23 an open day which is perhaps the fundamental challenge evident from this work. 


\section{$1 \quad$ Research Limitations and further research}

2 This study is designed only to be exploratory in nature and participants were drawn

3 from home/EU applicants for business related courses at two UK post-92 universities.

4 Further qualitative work exploring views from a broader sample of participants may

5 offer further insight into the research questions. For example a comparison with

6 international students, or a cross faculty sample from a wider range of universities,

7 including representation from 'Russell group' institutions, are recommended.

8 Replication in other country markets is also desirable.

9 Whilst this study considers the impact of the servicescape on student choice, it

10 doesn't consider the impact of the servicescape on existing students. To investigate the

11 impact of the university environment on students in the longer term would offer a

12 number of benefits to both educators and managers and could offer further insight into

13 facilitating student engagement. A longitudinal study would be necessary to explore

14 this.

15 Therefore although it begins the process, it is beyond the scope of this

16 exploratory work to offer a specific empirical model that allows conceptualisation and

17 management of the HE servicescape. This however, would be desirable from both an

18 academic and practitioner perspective and further qualitative and quantitative work is a

19 logical progression. 


\section{Bibliography}

2 Allen, D. E. (2002). Toward a Theory of Consumer Choice as Sociohistorically Shaped

3 Practical Experience: The Fits-Like-a-Glove (FLAG) Framework. Journal of Consumer

4 Research, 28 (4), 515-532.

5 Angulo, F., Pergelova, A., \& Rialp, J. (2010). A market segmentation approach for 6 higher education based on rational and emotional factors. Journal of Marketing for

7 Higher Education, 20 (1), 1-17.

8 Aubert-Gamet, V. (1997). Twisting servicescapes: diversion of the physical

9 environment in a re-appropriation process. International Journal of Service Industry

10 Management, $8(1), 26-41$.

11 Aubert-Gamet, V., \& Cova, B. (1999). Servicescapes: From modern non-places to 12 postmodern common places. Journal of Business Research , 44 (1), 37-45.

13 Baker, S., \& Brown, B. (2007). Images of excellence: constructions of institutional 14 prestige and reflections in the university choice process. British Journal of Sociology of 15 Education, 28 (3), 377-391.

16 Bennett, R., \& Ali-Choudhury, R. (2009). Prospective Students' Perceptions of

17 University Brands: An Empirical Study. Journal of Marketing for Higher Education , $1819(1), 85-107$.

19 Bitner, M. J. (1992). Servicescapes: The Impact of Physical Surroundings on Customers 20 and Employees. Journal of Marketing , 57-71.

21 Bonnin, G. (2006). Physical environment and service experience: An appropriation22 based model. Journal of Services Research, 6 (special issue), 45-65.

23 Booms, B., \& Bitner, M. (1981). Marketing strategies and organization structures for 24 service firms. In J. H. Donnelly, \& W. R. George (Eds.), Marketing of Services (pp. 4725 52). Chicago: American Marketing Association.

Bradley, J. (2013). Integrity in higher education marketing? A typology of misleading data-based claims in the university prospectus. International Journal for Educational Integrity, 9 (2), 74-88.

Briggs, S. (2006). An exploratory study of the factors influencing undergraduate student choice: the case of higher education in Scotland. Studies in Higher Education , 705-722.

Briggs, S., \& Wilson, A. (2007). Which university? A study of the influence of cost and information factors on Scottish undergraduate choice. Journal of Higher Education

33 Policy and Management, 29 (1), 57-72.

34 Brown, C., Varley, P., \& Pal, J. (2009). University course selection and services

35 marketing. Marketing Intelligence and Planning , 27 (3), 310-325.

36 Cabrera, A. F., \& La Nasa, S. M. (2000). Understanding the college choice process.

37 New Directions for Institutional Research, 107 (Fall), 5-22. 
1 Chapleo, C. (2010). What defines "successful" university brands? International Journal

2 of Public Sector Management, 23 (2), 169-183.

3 Chisnall, P. M. (1992). Marketing Research. Maidenhead: McGraw Hill.

4 Cohen, D., \& Crabtree, B. (2006, July). Semi structured interviews. Retrieved from

5 Qualitative Research Guidelines Project: http://www.qualres.org/HomeSemi-3629.html

6 Connor, H., Burton, R., Pearson, R., Pollard, E., \& Regan, J. (1999). Making the Right

7 Choice. How students choose universities and colleges. Institute of Employment

8 Studies.

9 Dawes, P. L., \& Brown, J. (2002). Determinants of Awareness, Consideration and

10 Choice Set Size in University Choice. Journal of Marketing for Higher Education , 12

11 (1), 49-75.

12 Dawes, P. L., \& Brown, J. (2008). The Composition of Consideration and Choice Sets 13 in Undergraduate University Choice: An Exploratory Study. Journal of Marketing for 14 Higher Education, 14 (2), 37-59.

15 Diamond, A., Vorley, T., Roberts, J., \& Jones, S. (2012). Behavioural Approaches to 16 Understanding Student Choice. York: The Higher Education Academy.

17 Dolan, P., Hallsworth, M., Halpern, D., King, D., \& Vlaev, I. (2010). MINDSPACE:

18 Influencing Behaviour through Public Policy. London: Institute for Government.

19 Donovan, R. J., \& Rossiter, J. R. (1982). Store Atmosphere: An Environmental

20 Psychology Approach. Journal of Retailing , 58 (1), 34-57.

21 Eroglu, S. A., Machleit, K., \& Barr, T. F. (2005). Perceived retail crowding and 22 shopping satisfaction: the role of shopping values. Journal of Business Research, 58 23 (5), 1146-53.

24 Esbjerg, L., \& Bech-Larsen, T. (2009). The brand architecture of grocery retailers: setting material and symbolic boundaries for consumer choice. Journal of Retailing \& 26 Consumer Services, 16 (1), 414-423.

27 Gibbs, P. (2001). Higher Education as a Market: A problem or solution? Studies in 28 Higher Education, 26 (1), 85-94.

29 Hanna, S., \& Rowley, J. (2011). Towards a Strategic Place Brand-Management Model.

30 Journal of Marketing Management , 27 (5/6), 458-476.

31 Harris, L., \& Ezeh, C. (2008). Servicescape and loyalty intentions: an empirical 32 investigation. European Journal of Marketing , 42 (3/4), 390-422.

33 Hemsley-Brown, J., \& Oplatka, I. (2006). Universities in a competitive marketplace - a 34 systematic review of the literature on higher education marketing. International Journal 35 of Public Sector Management, 19 (4), 316-338.

36 Ivy, J. (2008). A new higher education marketing mix: the 7Ps for MBA marketing.

37 International Journal of Educational Management , 22 (4), 288-299. 
1 Jacoby, J. (2002). Stimulus-Organism-Response Reconsidered: An Evolutionary Step in

2 Modeling (Consumer) Behaviour. Journal of Consumer Psychology, 12 (1), 51-57.

3 Jarvis, P. (2000). The changing university: meeting a need and needing to change.

$4 \quad$ Higher Education Quarterly, 54 (1), 43-67.

5 Kaplan, S. (1995). The restorative benefits of nature: toward an integrative framework.

6 Journal of Environmental Psychology , 15 (3), 169-182.

7 Kim, J. K., \& Gasman, M. (2011). In search of a "good college": Decisions and

8 determinations behind Asian American students' college choice. Journal of College

9 Student Development, 52 (6), 706-728.

10 Kotler, P. (1973). Atmospherics as a Marketing Tool. Journal of Retailing , 49 (4), 48-

1164.

12 Krejcie, R. V., \& Morgan, D. W. (1970). Determining sample size for research

13 activities. Educational and Psychological Measurements , 30, 607-610.

14 Lipowski, M. (2014). Student as Consumer - benefits of being an academic city.

15 Management, Knowledge and Learning International Conference, (pp. 811-820).

16 Portoroz, Slovenia.

17 Mari, M., \& Poggesi, S. (2013). Servicescape cues and customer behaviour: a

18 systematic literature review and research agenda. The Service Industries Journal , 33

19 (2), 171-199.

20 Maringe, F. (2006). University and course choice. Implications for positioning,

21 recruitment and marketing. International Journal of Educational Management, 20 (6),

$22 \quad 466-479$.

23 Mason, M. (2010). Sample Size and Saturation in PhD Studies Using Qualitative

24 Interviews. Forum: Qualitative Social Research .

Massey, D. (1994). A Global Sense of Place. In Space, Place and Gender. Minneapolis:

26 University of Minnesota Press.

Mazzarol, T. (1998). Critical success factors for international education marketing.

International Journal of Educational Management , 12 (4), 163-175.

Mehboob, F., Shah, S. M., \& Bhutto, N. A. (2012). Factors influencing student's enrollment decisions in selection of higher education institutions (HEIs).

Interdisciplinary Journal of Contemporary Research in Business , 4 (5), 558-568.

Mehrabian, A., \& Russell, J. (1974). An Approach to Environmental Psychology.

33 Cambridge, Mass: MIT Press.

Miles, M. B., \& Huberman, A. M. (1994). Qualitative Data Analysis. New York: Sage . 
1 Moogan, Y. J., Baron, S., \& Bainbridge, S. (2001). Timings and trade-offs in the 2 marketing of higher education courses: a conjoint approach. Marketing Intelligence and 3 Planning, $19(3), 179-187$.

4 Moogan, Y. J., Baron, S., \& Harris, K. (1999). Decision Making Behaviour of Potential $5 \quad$ Higher Education Students. Higher Education Quarterly, 53 (3), 211-228.

6 Moogan, Y., \& Baron, S. (2010). An analysis of student characteristics witin the student 7 decision making process. Journal of Further and Higher Education, 27 (3), 271-287.

8 Nilsson, E., \& Ballantyne, D. (2014). Reexamining the place of servicescape in 9 marketing: a service-dominant logic perspective. Journal of Services Marketing , 28 (5), $10 \quad 374-379$.

11 Obermeit, K. (2012). Students' choice of universities in Germany:structure, factors and 12 information sources used. Journal of Marketing for Higher Education, 22 (2), 206-230.

13 Palacio, A. B., Meneses, G. D., \& Perez Perez, P. J. (2002). The configuration of the 14 university image and its relationship with the satisfaction of students. Journal of 15 Educational Administration, 40 (5), 486-505.

Pampaloni, A. (2010). The influence fo organizational image on college selection: what students seek in institutions of higher education. Journal of Marketing for Higher Education , 19-48.

Petruzzellis, L., D'Uggento, A. M., \& Romanazzi, S. (2006). Student satisfaction and

20 quality of service in Italian universities. Managing Service Quality , 16 (4), 349-364.

Price, I., Matzdorf, F., Smith, L., \& Agahi, H. (2003). The impact of facilities on student choice of university. Facilities , 21 (10), 212-222.

Radcliffe, D., Wilson, H., Powell, D., \& Tibbetts, B. (2008). Designing Next Generation Places of Learning: Collaboration at the Pedagogy-Space-Technology Nexus. Australian Learning and Teaching Council.

Reay, D. (1998). 'Always knowing' and 'never being sure': Familial and institutional habituses and higher education choice. Journal of Educational Policy, 13 (4), 519-529.

Rosenbaum, M. (2005). The symbolic servicescape: your kind is welcomed here. Journal of Consumer Behaviour , 4 (4), 257-267.

30 Rosenbaum, M., \& Massiah, C. (2011). An expanded servicescape perspective. Journal 31 of Service Management, 22 (4), 471 - 490.

Rosenbaum, M., \& Montoya, D. (2007). Am I welcome here? Exploring how ethnic consumers assess their place identity. Journal of Business Research , 60 (3), 206-214.

34 Saunders, M., Lewis, P., \& Thornhill, A. (2009). Research Methods for Business

35 Students. Harlow: Pearson Education Limited.

36 Schmitt, B. (1999). Experiential Marketing: A New Framework for Design and

37 Communications. Design Management Journal , 10 (2), 10-16. 
1 Tombs, A., \& McColl-Kennedy, J. R. (2003). Social-servicescape conceptual model.

2 Marketing Theory, 3 (4), 447-475.

3 Turley, L. W., \& Milliman, R. E. (2000). Atmospheric Effects on Shopping Behavior: A

4 Review of the Experimental Evidence. Journal of Business Research , 49 (2), 193-211.

5 Velarde, M. G., Fry, G., \& Tveit, M. (2007). Health effects of viewing landscapes -

6 Landscape types in. Urban Forestry and Urban Greening , 6 (4), 199-212.

7 Veloutsou, C., Lewis, J. W., \& Paton, R. A. (2004). University selection: information

8 requirements and importance. International Journal of Educational Management , 160-

9171.

10 Veloutsou, C., Lewis, J. W., \& Paton, R. A. (2004). University selection: information 11 requirements and importance. International Journal of Educational Management , 18

12 (3), 160-171.

13 Veloutsou, C., Paton, R., \& Lewis, J. (2005). Consultation and reliability of information 14 sources pertaining to university selection. Some questions answered? International 15 Journal of Educational Management, 19 (4), 279-291.

16 Voss, C., Roth, A. V., \& Chase, R. B. (2008). Experience, Service Operations Strategy 17 and Services as Destinations: Foundations and Exploratory Investigation. Production 18 and Operations Management, 247-266.

19 Warnaby, G. (2009). Towards a Service-dominant Place Marketing Logic. Marketing

20 Theory, $9(4), 403-423$.

21 Zeithaml, V., Parasuraman, A., \& Berry, L. (1985). Problems and Strategies in Services

22 Marketing. Journal of Marketing , 49 (2), 33-46.

23 Zomerdijk, L. G., \& Voss, C. A. (2010). Service design for experience-centric services.

24 Journal of Service Research, 67-82. 